\title{
MANGANESE AND THE GROWTH OF PHYTOPLANKTON
}

\author{
By H. W. Harvey, Sc.D., F.R.S.
}

Hydrographer at the Plymouth Laboratory

(Text-figs. I-2)

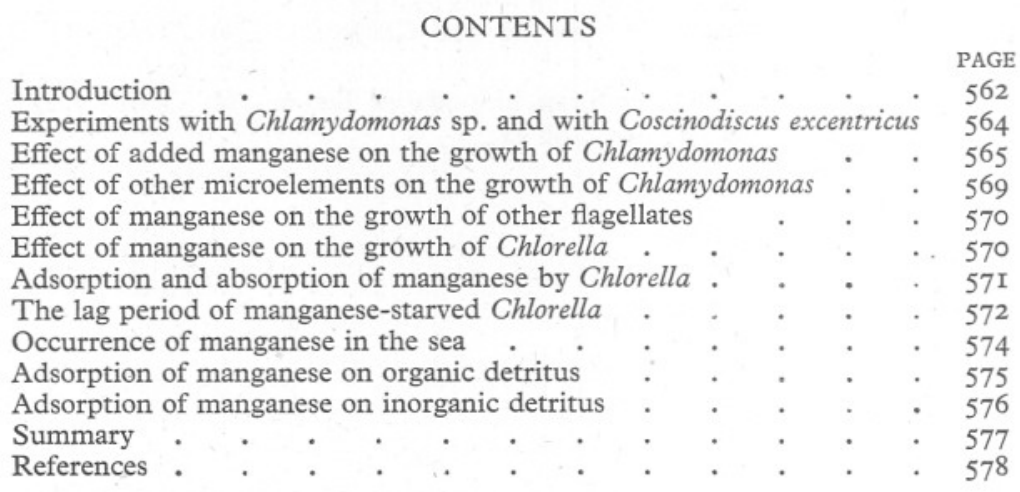

\section{INTRODUCTION}

Several marine plants grow at very different rates when kept in sea water collected from different positions and depths, after the waters have been heated to kill the naturally occurring organisms and have been enriched with phosphate, nitrate, silicate and iron. Instances have been recorded where a water, treated in this manner, has proved completely infertile towards one or other species of diatom introduced into it.

There is also evidence that in the sea, in nature, different bodies of water may support less, or more, rapid growth of phytoplankton for reasons other than their content of available phosphorus, nitrogen and silica. Hart (I94I) records that the plant life in the Scotia Sea, fed by a current which has washed outlying islands of the Antarctic continent and passed over a submarine ridge, is twice as great as elsewhere in corresponding latitudes. He attributes this heavier development of plant life to some constituent in the water derived from land drainage.

As yet there is no further direct evidence that, in nature, trace elements other than combined nitrogen and phosphorus affect the rate of phytoplankton growth, nor that the minute quantities of organic matter in solution play a part in regulating the growth of one or other species, but experimental evidence is suggestive. 
Some of this experimental evidence may be epitomized. It is generally recognized that for a vigorous growth of diatoms in culture it is necessary to add iron, either as an iron salt, as a trace of ferric hydroxide, or of the ferric phosphate precipitate formed on adding the Allen-Miquel nutrient solutions, or as an integral part of some stimulating addition such as soil or yeast or algal extract.

The following experiments proved instructive: samples of inshore waters, relatively rich in iron compared with water further out to sea and containing the natural community of phytoplankton organisms, were collected during the spring of 1946 and enriched with nitrate and phosphate, some with iron citrate also. They were kept aerated in a north window. Growth of the mixed communities of planktonic diatoms was more vigorous and the final crop greatest in the flasks to which iron citrate had been added. The natural inshore sea waters contained insufficient available iron for maximum growth rate or for a maximum crop. That iron is not the only minor constituent sometimes lacking in sea waters, other than sources of available phosphorus and nitrogen, is. shown by diatom growth experiments in Japanese and English Channel waters. Matudiara (1939) found considerable differences in the proliferation of the diatoms Nitzschia closterium and Skeletonema costatum when grown in samples of water taken from different depths and positions in the sea, after the waters had been heated and enriched with nitrate, phosphate, silicate and iron. Harvey (1939) found differences in the growth of Ditylium brightwelli in different waters which had been heated and enriched with nitrate, phosphate, iron, silicate and manganese also. A further instance of the different capability of sea waters to support plant growth other than owing to their nitrogen-phosphateiron content, has been supplied by de Valera (1940), who found that the sporeling of the sea weed, Enteromorpha, would grow more rapidly in water taken from the algal zone than in water collected from further out to sea. Later Suneson (1943) showed that extracts of algae, or even contact with algae, would render enriched sea water capable of supporting more rapid growth of Enteromorpha and of Ulva.

These differences between one sea water and another are not always, or wholly, due to variable concentrations of inorganic constituents essential for plant life. Allen (I9I4) found that an addition of organic substances, occurring in Ulva extract or in natural sea water, was essential for the growth of the diatom Thalassiosira gravida in artificial sea water. The writer (1939), in a series of experiments with Ditylium brightwelli, found that at least two organic substances or groups of substances were necessary for continued growth. One of these, which could be extracted from either sea water, soil or algal extracts, was probably a sulphur containing organic acid and could be replaced by several organic compounds containing divalent sulphur-cystine, methionine, thiamin, impure biotin and (in later unpublished experiments) by sodium sulphide. The other could be replaced by alanine. However, this was only a 
first step towards finding the organic essentials for optimum growth, because relatively large quantities, several milligrams per litre, of the pure chemicals had to be used, more than ever likely to occur in a natural fully 'fertile' sea water. These experiments on organic growth stimulants also indicated that variability of trace elements, other than iron and manganese, in different sea waters may perhaps play some part in regulating the rate of diatom growth. Later Levring (1945) has shown that it is only the extracts of some species of seaweeds which stimulate diatom growth, not others; he, Kylin (I94I-5), and Algeus (1946) have further added to the list of pure organic substances which stimulate the growth of marine plants.

In nature the ever-varying standing crop of phytoplankton, the primary food of marine animals, is a momentary balance resulting from the rate the plants have been multiplying and the rate they have been eaten. In most seas, other than the nutrient rich Antarctic, the low concentrations of available nitrogen and phosphorus impose a brake on the rate of multiplication since these nutrients are usually in insufficient concentration for most rapid growth.

There can be little doubt that low concentrations of available iron often act in the same way.

It now seems probable that shortage of another trace element, manganese, may at times exacerbate these natural brakes upon the rate of multiplication of at least some species of phytoplankton.

\section{EXPERIMENTS WITH CHLAMYDOMONAS SP. AND WITH COSCINODISCUS EXCENTRICUS}

A marine Chlamydomonas, isolated from Oslo Fiord by Mrs Foyn, has been in culture since 1928, for many years in an artificial sea water made from laboratory reagents.

When subcultured into sea water, obtained from the entrance to Plymouth Sound at high water in the late summer of 1945, which had been enriched with nitrate, phosphate and iron citrate, this flagellate made poor growth, the cells becoming small. On further subculture growth almost ceased. Other samples of inshore water obtained at intervals during the autumn proved similarly infertile.

On the other hand, when cultured in samples of water obtained some 15 miles offshore in late August and early November, the flagellate grew well.

It was found that very small additions of manganese, well within the range of I-IO mg. $\mathrm{Mn} / \mathrm{m}^{3}$ found by analysis of Pacific and Baltic waters, rendered these infertile autumn inshore waters fertile. Heavy crops of full-sized flagellate cells would then grow in it after enrichment.

Experiments were made with inshore and offshore water collected in August, enriched with equal quantities of nitrate, phosphate and iron, and inseminated with equal numbers of the diatom Coscinodiscus excentricus. 
A final crop of I8I diatoms/c.c. was produced in the inshore water. The addition of manganese in these experiments gave rise to a crop of 220 diatoms/c.c. In the offshore water 559 diatoms/c.c. were produced, with added manganese 606. Lack of this element did not account for the relative infertility of the inshore water.

A similar experiment was made with waters collected in November. In the inshore water 392 diatoms/c.c. were produced and the addition of $\mathrm{Mn}$ raised the crop to 493 per c.c. In the offshore water, likewise sterilized by heat and enriched in identical manner, only 122 diatoms/c.c. were produced and the addition of manganese did not increase the production.

While the addition of manganese had only a minor effect on the growth of Coscinodiscus in these experiments, no water, which was infertile to Chlamydomonas after enrichment, failed to produce a large crop of this flagellate after addition of manganese.

\section{Effect of added Manganese on the Growth of CHLAMYdomonaS}

Water collected at the entrance to Plymouth Sound in early October was filtered, heated to kill any organisms which had passed the filter, and enriched with $8000 \mathrm{mg}$. $\mathrm{N}$ as nitrate, $400 \mathrm{mg}$. P as phosphate and $80 \mathrm{mg}$. Fe $/ \mathrm{m}^{3}$ as citrate. The water was then inseminated with Chlamydomonas, which had been grown in a similar infertile water and was showing the effects of manganese starvation-the cells had multiplied slowly and many were less than normal size. Roughly, 3 cells $/ \mathrm{mm} .^{3}$ were added. The water was filled into a series of small flasks, manganous chloride added, and the flasks placed below a fluorescent strip light.

Fig. I $a$ shows the crop which was produced after 9, II, I5 and 22 days of continuous illumination.

As little as $0.1 \mathrm{mg} . \mathrm{Mn} / \mathrm{m} .^{3}$ had a significant effect during the early stages of growth; neither the effect of this nor of $0 \cdot 25 \mathrm{mg}$. $/ \mathrm{m} .{ }^{3}$ persisted long enough to permit a considerable crop to develop. However, the addition of $0.5 \mathrm{mg} . / \mathrm{m}^{3}$ was sufficient to allow the utilization of more than half the large quantity of phosphate in the enriched sea water.

The final crop obtained due to the addition of 0.1 and $0.25 \mathrm{mg} . \mathrm{Mn} / \mathrm{m} .^{3}$ is less than one-fifth or one-half, respectively, of the crop due to the addition of $0.5 \mathrm{mg} . \mathrm{Mn} / \mathrm{m} .^{3}$ There would appear to be a limiting concentration below which manganese is not fully made use of -in this instance rather less than $0.5 \mathrm{mg} . / \mathrm{m} .{ }^{3}$ plus that which was in the water initially and the minute amount added with, and in, the cells used to inoculate. Two later experiments with an infertile inshore water showed that the addition of 0.5 and even of $\mathrm{I} \cdot 0 \mathrm{mg} . / \mathrm{m} .^{3}$ did not provide sufficient to allow a considerable crop to develop, although larger quantities led to heavy crops. 

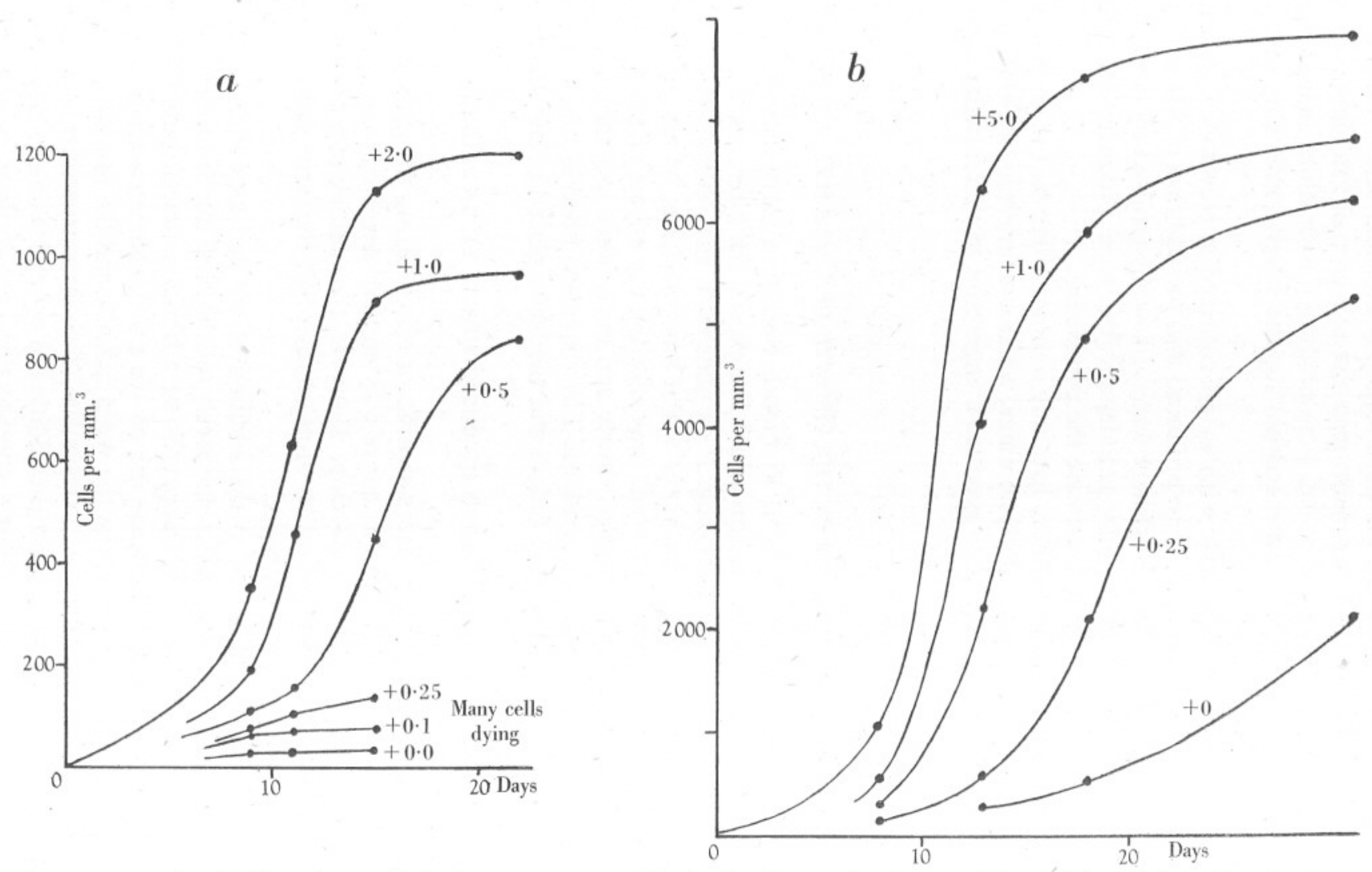

Fig. I. $a$, growth of Chlamydomonas in inshore sea water enriched with nitrate, phosphate, and iron, with additions of $0.1,0.25,0.5$, $\mathrm{I} \cdot 0$ and $2.0 \mathrm{mg} . \mathrm{Mn} / \mathrm{m}^{3} \quad b$, growth of Chlorella in same medium, with additions of $0.25,0.5, \mathrm{I} \cdot 0$ and $5 \cdot 0 \mathrm{mg}$. Mn $/ \mathrm{m} .^{3}$ 
Hence these experiments provide no absolute value of the minimum concentration necessary for prolific growth, but they do show that the addition of as little as $0.5 \mathrm{mg} . / \mathrm{m}^{3}$ may just tip the scale.

In these and subsequent experiments the water used had been filtered, either through a Berkfeld candle long in use for filtering sea water or through filter-paper, and the waters had been heated, usually to $70-90^{\circ} \mathrm{C}$., in order to kill organisms which had passed the filter. It was, therefore, desirable to find out if this filtration robbed the waters of any of their naturally occurring manganese by adsorption, and to find whether heating affected the fertility of the water towards Chlamydomonas. Samples of the same water were (a) passed through the Berkfeld candle, $(b)$ passed through a filter-paper. These and also the same water unfiltered were heated, enriched and inseminated with manganese-starved Chlamydomonas. Similar growth took place in all three waters and the growth was increased to the same extent by additions of the same small quantity of manganese. The experiments gave no reason to suppose that any manganese initially present in the raw waters was adsorbed on either filter. In a subsequent experiment it was observed that an unfiltered water containing much plankton and detritus gave less increased growths with added manganese than when the particulate organic matter had been removed by filtration before the manganese chloride was added. The adsorption upon organic detritus of manganese at the great dilutions which occur in the sea was later investigated (p. 575).

In order to find whether the preliminary heating before enrichment in any way affected the fertility of the water, it was necessary to free a sample from included organisms. A Seitz filter had proved effective for this purpose (Schreiber, I929) but experiment showed that even after being well washed the asbestos pad gave off a trace of manganese into the water, rendering a heated inshore water more fertile towards Chlamydomonas. A sample of inshore water was, therefore, rough filtered and divided into two parts. One portion was passed through a Seitz filter, the other portion heated to $95^{\circ} \mathrm{C}$. and cooled. Part of this heated water was passed through the Seitz filter; both this and the remainder and the unheated Seitz filtered water were enriched to the same extent with nutrient salts and iron, and $40 \mathrm{mg} . \mathrm{Mn} / \mathrm{m} \cdot{ }^{3}$ added to all three. This heavy addition of manganese was made in order to smooth out any differences due to manganese derived from passage through the Seitz. filter. Identical growths of Chlamydomonas were obtained in all three watersunheated, heated, and both heated and Seitz filtered. The experiment provided no grounds for supposing that the preliminary heat treatment affected the fertility of the water, provided the enrichment with iron was made after heating and cooling (Harvey, I937) as was done in all the experiments. In many of the experiments the plants were illuminated continuously, a condition which does not occur in nature. An inshore water was therefore enriched, inseminated and kept under different conditions of illumination. 
The experiment (Table I) gave no indication that results brought about under continuous illumination would not occur under natural conditions of alternate light and darkness. It also showed that addition of manganese was equally effective in increasing growth in bright light as in the relatively dim light of October days. This was of interest since experiments (unpublished) with the diatom Ditylium had suggested, but not proved, that addition of this element had marked effect on growth in a particular sea water in dim light but less effect in bright light; subsequently Emerson \& Lewis (1939) found that manganese deficiency affects photosynthesis in weak light.

In these experiments manganese was added as a divalent manganous salt. It is not known in what form the element occurs naturally in sea water, so the effect on Chlamydomonas was tried of adding heptavalent manganese. This, permanganate, is reduced in sea water and the product formed is likely to be

\section{TABLE I. EXPERIMENT 2-29 OCTOBER}

Filtered inshore water enriched with I000 mg. nitrate-N, $50 \mathrm{mg}$. phosphate-P and $20 \mathrm{mg}$. Fe, inseminated with Chlamydomonas

\begin{tabular}{|c|c|c|c|c|c|c|}
\hline \multirow[b]{2}{*}{ In north window: } & \multicolumn{5}{|c|}{ Cells $/ \mathrm{mm} \cdot{ }^{3}$ on day } & ' \\
\hline & 3 & 6 & IO & I4 & I8 & 25 \\
\hline Without addition & I & 一 & 6 & I9 & 24 & Cells dead \\
\hline With $5 \mathrm{mg} . / \mathrm{m}^{3} \mathrm{Mn}$ & 9 & 一 & 42 & 106 & 127 & II 5 \\
\hline \multicolumn{7}{|c|}{ In continuous illumination: } \\
\hline Without addition & IO & 一 & I7 & 8 & \multicolumn{2}{|c|}{ Cells dead } \\
\hline With $5 \mathrm{mg} . / \mathrm{m}^{3} \mathrm{Mn}$ & 90 & I35 & 145 & 132 & $7 \mathrm{I}$ & \\
\hline \multicolumn{7}{|c|}{$\begin{array}{l}\text { In continuous illumination } \\
\text { at about } \mathrm{I} / 20 \text { intensity: }\end{array}$} \\
\hline Without addition & 4 & IO & 6 & 4 & \multirow{2}{*}{\multicolumn{2}{|c|}{$\begin{array}{l}\text { Cells dead } \\
\text { IOO }\end{array}$}} \\
\hline With $5 \mathrm{mg} \cdot / \mathrm{m} .^{3} \mathrm{Mn}$ & $2 I$ & 90 & II3 & 127 & & \\
\hline
\end{tabular}

of as high a valency as the manganese occurring naturally in solution. The addition of the same quantity of the element in either the di- or the heptavalent form caused equal increases in growth, from which it is inferred that adding manganous manganese was not in any way different from increasing the manganese occurring naturally in the sea.

The effect of low concentration of manganese on the size of this flagellate is shown in the experiment of IO-I7 October. Chlamydomonas from a reasonably vigorous culture which had not been unduly starved of manganese was used to inseminate an infertile sea water enriched with $6000 \mathrm{mg}$. nitrate- $\mathrm{N}$, $300 \mathrm{mg}$. phosphate-P and $20 \mathrm{mg}$. Fe as citrate per $\mathrm{m}^{3}{ }^{3}$ This was distributed in flasks to which varying amounts of manganous chloride were added. On the seventh day of continuous illumination measurements were made of the average diameter of the cells (Table II).

It has been observed by A. Kylin (I943, I945) that the addition of a heavy dose of manganese to sea water, $250 \mathrm{mg}$. $\mathrm{Mn} / \mathrm{m} .^{3}$, stimulated the growth of sporelings of Ulva lactuca when nitrogen was supplied as nitrate, but not when supplied as ammonium. A vigorous culture of Chlamydomonas, which had 
been washed with inshore water by centrifuging and which was not manganese starved, was used to inseminate an inshore water enriched with phosphate, iron and with either nitrate or ammonium chloride. A substantial increase in growth rate was observed where $40 \mathrm{mg}$. $\mathrm{Mn} / \mathrm{m} .^{3}$ had been added. In this experiment (I9 September-30 October), sufficient $M n$ had been introduced

TABLE II. EXPERIMENT IO-I7 OCTOBER

\begin{tabular}{|c|c|c|c|}
\hline \multirow{2}{*}{$\begin{array}{l}\text { Mn added } \\
\left(\mathrm{mg} \cdot / \mathrm{m} .^{3}\right)\end{array}$} & \multicolumn{2}{|c|}{ Cells $/ \mathrm{mm}^{3}$, on day } & \multirow{2}{*}{$\begin{array}{c}\text { Mean } \\
\text { diameter } \\
(\mu)\end{array}$} \\
\hline & 5 & 7 & \\
\hline 0 & 49 & 100 & 6 \\
\hline I & 230 & 840 & $8 \frac{1}{2}$ \\
\hline 2 & $4 \mathrm{I} 5$ & 890 & $9 \frac{1}{2}$ \\
\hline 5 & 376 & 940 & $9 \frac{1}{2}$ \\
\hline
\end{tabular}

in the cells of the inoculum for an almost full crop to develop without further addition of this element. The results are shown in Table III. It appears that manganese increases the growth rate of this plant whether nitrogen is supplied in either form and that, in this respect, the flagellate differs from Ulva. Noack \& Pirson (1939) have also found that Chlorella responds to manganese with nitrogen supplied in either form.

\section{TABle III. EXPeriment ig SePtember-30 OCtober}

\begin{tabular}{|c|c|c|c|c|c|c|c|c|c|c|c|c|}
\hline \multicolumn{3}{|c|}{ Enrichment } & \multirow{2}{*}{$\begin{array}{l}\text { Addition } \\
\mathrm{mg} \cdot / \mathrm{m} \cdot{ }^{3} \mathrm{Mn}\end{array}$} & \multicolumn{9}{|c|}{ Cells $/ \mathrm{mm} .^{3}$ after day } \\
\hline $\mathrm{mg} \cdot / \mathrm{m} \cdot{ }^{3} \mathrm{~N}$ & $\mathrm{mg} \cdot / \mathrm{m} \cdot{ }^{3} \mathrm{P}$ & $\mathrm{mg} . / \mathrm{m} \cdot{ }^{3} \mathrm{Fe}$ & & 10 & 6 & 9 & I2 & I5 & I9 & 22 & 27 & $4 \mathrm{I}$ \\
\hline $\begin{array}{c}\text { I000 } \\
\text { (as nitrate) }\end{array}$ & 50 & 40 & 0 & Io & $7 \mathrm{I}$ & I33 & I56 & I56 & 169 & I5I & 130 & 85 \\
\hline $\begin{array}{c}\text { rooo } \\
\text { (as nitrate) }\end{array}$ & 50 & 40 & 20 & Io & I59 & I 45 & 182 & I 88 & I 74 & I52 & 156 & 68 \\
\hline $\begin{array}{c}500 \\
\text { (as nitrate) }\end{array}$ & 25 & 40 & $\circ$ & Io & $6 I$ & 77 & 93 & 105 & - & 100 & 65 & 55 \\
\hline $\begin{array}{c}500 \\
\text { (as nitrate) }\end{array}$ & 25 & 40 & 20 & Io & - & 92 & IOI & II 8 & - & 94 & 96 & 49 \\
\hline $\begin{array}{c}\text { rooo } \\
\text { (as ammonium) }\end{array}$ & 50 & 40 & $\circ$ & Io & $7 \mathrm{I}$ & 123 & 170 & I54 & - & - & - & 一 \\
\hline $\begin{array}{c}\text { I000 } \\
\text { (as ammonium) }\end{array}$ & 50 & 40 & 20 & IO & 185 & I 44 & 182 & I53 & - & - & - & - \\
\hline $\begin{array}{c}500 \\
\text { (as ammonium) }\end{array}$ & 25 & 40 & 0 & Io & 65 & 90 & 90 & 104 & - & - & - & - \\
\hline $\begin{array}{c}500 \\
\text { (as ammonium) }\end{array}$ & 25 & 40 & 20 & Io & 108 & 95 & 107 & I 22 & - & - & - & - \\
\hline
\end{tabular}

EfFect of other Microelements on the Growth of ChLAMYDOMONAS In previous experiments (Harvey, 1939) it was observed that the addition of trace elements to sea water enriched with iron and manganese increased the growth of the diatom Ditylium brightwelli; the addition of coal ash dissolved in hydrochloric acid, considered likely to contain a representative collection of metals necessary for plant growth, was effective, but no attempt was made to ascertain the salts in this mixture which stimulated growth. 
Riley (I943) has observed that the addition of a gallium salt stimulated the growth of the diatom Nitzschia closterium in nutrient-deficient sea water but not when an ample supply of nitrate and phosphate was present.

Amongst the growing list of microelements which are either essential or stimulants for higher plants, several occur in sea water at less than I mg. $/ \mathrm{m} .{ }^{3}$, and a number of trace elements are concentrated by marine algae to the extent of several grams per ton.

It was, therefore, of interest to find whether the addition of such elements to sea water, enriched with nitrate, phosphate, iron and manganese, would enhance the growth rate of Chlamydomonas. Using inshore sea water collected during the winter of $1945-6$, no increased division rate of the flagellate was caused by the addition of $2 \mathrm{mg}$. $/ \mathrm{m}^{3}$ of $\mathrm{Ni}, \mathrm{Ga}, \mathrm{Co}, \mathrm{Zr}, \mathrm{Mo}, \mathrm{La}, \mathrm{V}, \mathrm{Ge}$, plus Io $\mathrm{mg} . / \mathrm{m} .^{3}$ of $\mathrm{Zn}$ and $\mathrm{Cu}$. Nor was any increase in growth rate caused by the addition of the ash of Ulva lactuca dissolved in hydrochloric acid, although this did bring about a greater final crop, apparently due to its phosphate content.

Hence it may be concluded that the inshore sea waters contained sufficient micronutrients for optimum growth rate, with the exception of available $\mathrm{P}$, $\mathrm{N}, \mathrm{Fe}$ and $\mathrm{Mn}$.

Experiments with diatoms (Harvey, 1937; Levring, 1945) have shown that the addition of divalent sulphur in the form of cystine increases the growth rate of these plants, and subsequent experiments showed that addition of sulphide had a similar effect. Experiments with Chlamydomonas showed no increased growth rate due to the addition of I mg. divalent sulphur/litre in the form of either cystine or sodium sulphide.

\section{Effect of Manganese on the Growth of other Flagellates}

I am indebted to Dr M. W. Parke for cultures of two brown Chrysomonads and a red Cryptomonad. These flagellates had been obtained from the Irish Sea and cultured in sea water enriched with phosphate, nitrate and soil extract.

On subculturing into an inshore water enriched with phosphate, nitrate and iron citrate, the growth was slow and limited. These subcultures were kept in flasks in a north window on a rotating table in order that each should obtain the same illumination, together with flasks to which had been added $5 \mathrm{mg}$. $\mathrm{Mn} / \mathrm{m}^{3}$ and which had been inseminated with the same quantity of the flagellates. In these latter the growth was more rapid and the final crop greater. They responded to the increase in manganese as did Chlamydomonas.

\section{EFfect of Manganese on the Growth of CHLORELLA}

A culture of a marine species of Chlorella, in enriched sea water with soil extract for which I am also indebted to Dr Parke, was subcultured in the same way. There was no increase in growth rate or final crop due to added manganese; however, at the third subculture both the rate of growth and final crop 
were greatly increased by added manganese. The parent cells grown with soil extract were sufficiently rich in manganese to allow many divisions to take place before the low concentration of this element in the inshore water affected their growth.

This third subculture without added manganese, being of cells to some degree starved of this element, was used to inseminate inshore water to which varying quantities of manganese had been added after enrichment with nitrate, phosphate and iron. The flasks were kept under a strip-light as in previous experiments; each contained 33 cells $/ \mathrm{mm}^{3}$ at the start and counts were made at intervals. Data are shown in Table IV and in Fig. I $b$.

TABle IV. EXPeriment 20 December-2I JANUARy

\begin{tabular}{|c|c|c|c|c|c|}
\hline \multirow{2}{*}{$\begin{array}{l}\text { Manganese added } \\
\mathrm{mg} \cdot / \mathrm{m}^{3}\end{array}$} & \multicolumn{5}{|c|}{ Chlorella cells $/ \mathrm{mm} .^{3}$ on day } \\
\hline & I & 8 & I3 & I8 & $3 I$ \\
\hline 0.0 & 33 & I85 & 268 & $5 \mathrm{I} 7$ & $2125^{\star}$ \\
\hline 0.25 & 33 & - & 595 & 2100 & 5240 \\
\hline 0.5 & 33 & 291 & 2220 & 4860 & 6250 \\
\hline$I \cdot O$ & 33 & 520 & 4040 & 5910 & 6850 \\
\hline $5 \cdot 0$ & 33 & 1080 & 6340 & 7440 & 7850 \\
\hline
\end{tabular}

An examination of these population densities leads to two observations. If the increase in number of Chlorella cells after I3 or after I8 days is divided by the quantity of manganese added, this proportional increase is seen to be greatest where $0.5 \mathrm{mg}$. $\mathrm{Mn} / \mathrm{m}^{3}$ was added; a similar observation was made in the previous experiment with Chlamydomonas. If the growth rate is examined, this is seen to increase after the earlier period of illumination where $0.25-$ I mg. $\mathrm{Mn} / \mathrm{m} .^{3}$ had been added. Thus a lag period is indicated before the manganese exerts its full effect.

\section{Adsorption AND ABSorption of MANGANESE By CHLORELLA}

An experiment was designed to see whether Chlorella cells would at once adsorb a material quantity of manganese ions on their surface, from water containing a low concentration of the element, and retain or absorb sufficient of these ions, not allowing them to be de-adsorbed, when transferred to an infertile inshore water-sufficient to permit an increased growth rate. Equal volumes of a culture of manganese-starved cells were dosed with $5 \mathrm{mg}$. $\mathrm{Mn} / \mathrm{m} .^{3}$ and centrifuged at once, after Io min. and after I $8 \mathrm{hr}$., the liquid poured off and the cells transferred to infertile inshore water which had been enriched.

As control an equal volume of the culture, without prior treatment with manganese, was centrifuged and transferred to the inshore water. Growth was perceptibly increased by the shortest period of contact with $5 \mathrm{mg}$. $\mathrm{Mn} / \mathrm{m}^{3}$, increased still more by contact for rather more than Io min., and very markedly increased by contact for $\mathrm{I} 8 \mathrm{hr}$. 
It is significant that such short contact with manganese ions at such great dilution should allow an effective quantity to be retained by the plants. Presumably manganese was not only adsorbed on the surface but actually passed into the interior of the cells during the short period of contact with the manganese-enriched sea water.

Reference to published work on photosynthesis by freshwater species of Chlorella indicate that manganese penetrates the cell rapidly when added to the water. Pirson (1937) had found that when a relatively large quantity$55 \mathrm{mg} . \mathrm{Mn} / \mathrm{m}^{3}$ - was added to a culture of manganese-starved cells, it at once - 'augenblick'-increased the rate of photosynthesis. Emerson \& Lewis (I939) found that manganese played a major part in maintaining or restoring maximum photosynthetic activity and that 'under some circumstances it may have an effect within a short period after it is supplied'. The quantity added is not stated, but it seems usual in working with freshwater organisms to add much more than the minute amounts occurring in the sea or concerned with in the present investigation.

The next experiment was designed to see whether the growth of a considerable crop of Chlorella would abstract a material proportion of manganese added to sea water. A crop was grown in enriched water to which $5 \mathrm{mg}$. $\mathrm{Mn} / \mathrm{m} .{ }^{3}$ had been added. This was gently centrifuged and the centrifugate, containing some Chlorella cells, was further enriched with nutrient salts and iron. This nitrogen-phosphate-iron enriched centrifugate was divided, and I $\mathrm{mg} . \mathrm{Mn} / \mathrm{m} .^{3}$ added to one part. After illumination an obvious and marked increase in the second crop of Chlorella was seen in the flasks to which this I mg. $/ \mathrm{m}^{3}$ had been added. In an ancillary experiment no such difference was apparent between the growth of these cells in enriched inshore water dosed with 5 and $6 \mathrm{mg} . \mathrm{Mn} / \mathrm{m} .^{3}$ The result suggests that the first crop of Chlorella had abstracted a material proportion of the $5 \mathrm{mg}$. $\mathrm{Mn} / \mathrm{m} .^{3}$ added at the beginning of the experiment. This is in conformity with Thompson and Wilson's observation that the concentration of manganese in the sea is less when phytoplankton is abundant.

\section{The Lag Period of Manganese-starved Chlorella}

Several observations were made concerning the lag or pause before growth starts when cells, which have nearly ceased growth owing to lack of manganese, are subcultured. The experiment shown in Fig. $2 a$ indicates a lag of approximately 2 days irrespective of the manganese content of the water into which the cells were subcultured, although its addition greatly increased the subsequent growth rate of the cells. The experiment also indicates that, where cells growing rapidly in water with ample manganese are subcultured into inshore water, growth starts almost at once. 
With the aim of finding whether storage in the dark after adding manganese would reduce the lag period, a nitrogen-phosphate-iron enriched water was inseminated with Chlorella; to one portion $5 \mathrm{mg} . \mathrm{Mn} / \mathrm{m} .{ }^{3}$ were added, both

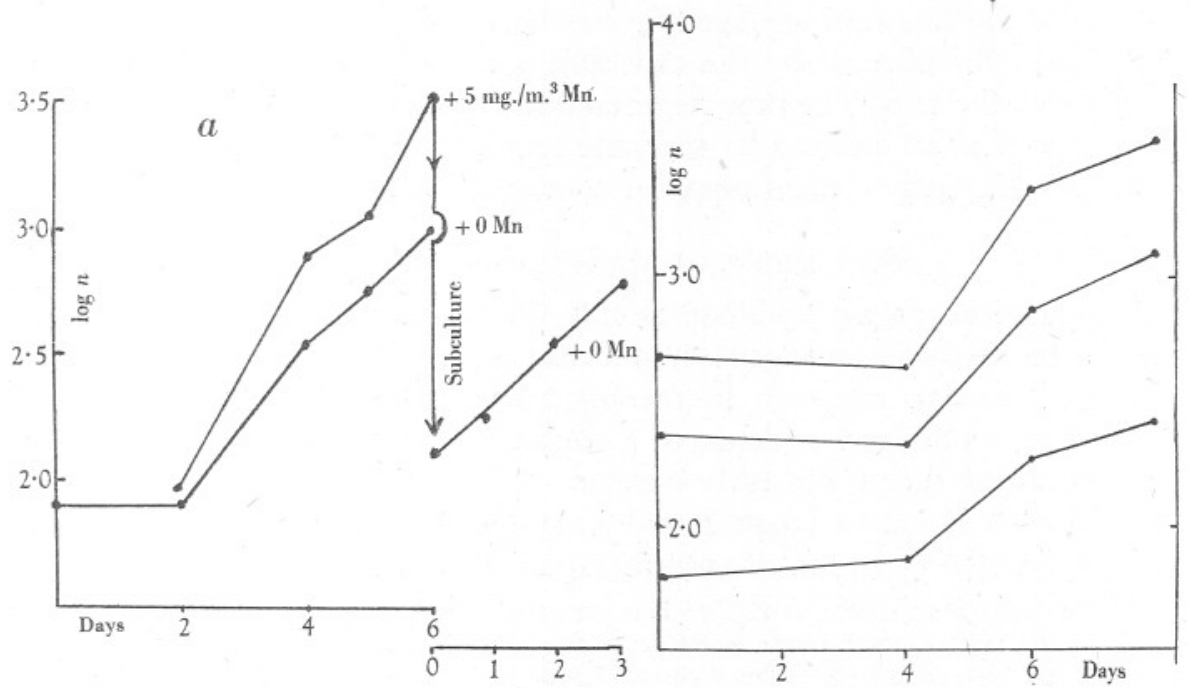

Fig. 2. Growth of manganese-starved Chlorella. a, the lag period and subsequent growth when transferred to sea water enriched with nitrate, phosphate and iron, without and with added manganese; the latter subcultured on the sixth day into enriched sea water. $b$, the effect of varying the quantity of inoculum on the lag period and subsequent growth rate. The number of cells per $\mathrm{mm}^{3}(n)$ is shown on a logarithmic scale.

portions were kept in the dark for 4 days; then the same quantity, $5 \mathrm{mg} . / \mathrm{m} .^{3}$, of manganese was added to the second portion, and both were illuminated. No difference was found in the lag period, which lasted less than $24 \mathrm{hr}$., or in the subsequent growth rate of the Chlorella (Table V).

\section{Table V. Growth of Chlorella (CELls/Mm. ${ }^{3}$ ) AFTER Storage IN DARK}

\begin{tabular}{|c|c|c|}
\hline & $\begin{array}{l}\text { Stored in the dark with } \\
5 \mathrm{mg} . \mathrm{Mn} / \mathrm{m}^{3}\end{array}$ & $\begin{array}{l}\text { Stored in the dark prior } \\
\text { to addition of } \mathrm{Mn} \\
\left(\mathrm{Cells} / \mathrm{mm}^{3}\right)\end{array}$ \\
\hline At start of insolation & $152 \pm I 2$ & $\mathrm{I} 49 \pm \mathrm{I} 2$ \\
\hline After 24 hours & $180 \pm 13$ & $173 \pm 12$ \\
\hline$\Rightarrow 48 \quad \%$ & $362 \pm 17$ & $378 \pm 22$ \\
\hline , 72 & $928 \pm 56$ & $835 \pm 45$ \\
\hline $96 \quad$, & $I 400 \pm 80$ & $I 320 \pm 80$ \\
\hline
\end{tabular}

When bacteria are subcultured into fresh nutritive media, the lag period before logarithmic growth commences is reduced by increasing the size of the inoculum or by adding filtered medium from the parent culture. Experiment 
showed that it is otherwise with Chlorella; increasing the inoculum (Fig. 2b) had no obvious effect upon the length of the lag period. ${ }^{1}$

These observations indicate that the lag was a resting stage induced by starvation of a necessary cell constituent, on this occasion manganese. Recovery from this resting stage requires both a supply of manganese which is very rapidly collected by the cells and light for internal changes to take place within the cells. The time required for recovery, the lag period, appeared to be little if at all affected by the time required by the cells to collect and absorb a sufficiency of manganese for continued growth.

\section{OCCURRENCE OF MANGANESE IN THE SeA}

Direct chemical analysis by Thompson \& Wilson (1935) has shown a variable content of dissolved manganese in ocean waters of the Pacific, ranging between I and Io $\mathrm{mg} . / \mathrm{m}^{3}$ In the plankton-rich waters of the San Juan Channel they obtained evidence of a seasonal variation, less being found in solution during spring and early summer.

Noddack \& Noddack (1940) found $4 \mathrm{mg} . \mathrm{Mn} / \mathrm{m} .{ }^{3}$ in water collected off the coast of Sweden by means of spectrographic analysis.

${ }^{1}$ In the experiment shown in Fig. $2 b$ it is seen that after expiration of the lag period the growth rate is greater where larger quantities of inoculum were added. A further experiment was made in which centrifugate from a parent culture was added to subcultures. This'addition increased the growth rate. A similar observation has been made with the diatom Nitzschia closterium. This evidence, although limited, suggests that the products of metabolism which dissolve from the cells into the water stimulate vegetative reproduction of Chlorella and Nitzschia, a somewhat unique diatom whose ready growth in culture is less susceptible to adverse conditions than most planktonic forms.

In contrast to these observations, Levring (1945) has found that water from an old culture of the diatom Skeletonema costatum appeared to contain substances inhibitory to the growth of this species, just as bacteria excrete inhibitory metabolic products which limit their growth in rich media long before the nutrients are exhausted.

The effect of metabolites discharged into the water from the same species and from other creatures-both plants and animals-upon the growth of phytoplankton organisms should repay further study. The classic experiment of Allen showed that the growth of diatoms in enriched sea water, collected inshore or from an aquarium, was often improved if the water was previously treated with charcoal or hydrogen peroxide or chlorine. This suggests the presence of inhibitory substances in the water which were adsorbed, oxidized or chlorinated respectively. Furthermore, the improved growths obtained by the use of Allen-Miquel solution, which produces a heavy precipitate in the water, compared with simple nitrogenphosphate-iron enrichment suggests that inhibitory substances may be carried down in the precipitate which is mostly removed before insemination with the diatom to be cultured. Matudiara (1939) observed that the great differences in growth of Skeletonema in waters collected from different depths, and similarly enriched, was still apparent if the waters were treated with Allen-Miquel solution in place of simple enrichment, but he found that greater growths of the Skeletonema occurred after Allen-Miquel treatment of the water than after simple enrichment. These observations confirm those of Allen and show that either inhibitory substances did not wholly cause the differences between one water and another, or, alternatively, were not entirely adsorbed from the water and carried down in the precipitate. As for the nature of these imaginary inhibitory substances, fungi are known to occur in the sea on algae (ZoBell 1946, pp. I3I-5) and not uncommonly on fish in aquaria; the writer has observed that algal extracts, set aside to undergo bacterial breakdown, become poisonous to diatoms if moulds develop on them. 
Thompson \& Wilson record that waters rich in phytoplankton contained less dissolved manganese, and they found that the ash of mixed plankton organisms, mainly diatoms, was singularly rich in this element, containing as much as $0.07 \%$. Correns (194I), quoted by Pettersson (1945), has also found that the shells of three species of Foraminifera taken from oceanic deposits contained between 0.01 and $0.02 \%$. On the other hand Cooper (1939) found that two plankton animals, Pleurobrachia and Sagitta, contained insignificant quantities of manganese.

From the foregoing experiments with autotrophic flagellates and Chlorella it is clear that manganese plays a role in plankton growth as expected by Thompson \& Wilson, and that phytoplankton collects a large proportion of the small quantity ever present in solution. In addition to being absorbed as an essential constituent, it is likely to be adsorbed on cell surfaces-a purely physical occurrence which would further deplete the sea of dissolved manganese. Experiment shows that this takes place.

\section{Adsorption of Manganese on Organic Detritus}

The following experiments were made to determine whether dead animal and vegetable matter would adsorb any material proportion of the very small quantity of manganese occurring in sea water.

Organic detritus was prepared by heating a tow-net catch of mixed diatoms and zooplankton, to kill the organisms, filtering and washing with filtered sea water. An inshore water was enriched with nitrate and phosphate and divided into 250 c.c. portions with: (a) the addition of organic detritus prepared as above; (b) the addition of an equal quantity of this organic detritus and also I mg. $\mathrm{Mn} / \mathrm{m}^{3}$; (c) no addition, to act as control. After standing for $24 \mathrm{hr}$. all three were filtered, heated to $70^{\circ} \mathrm{C}$., cooled, enriched equally with iron citrate, inseminated with the same quantity of a Chlamydomonas culture and distributed into small flasks. One flask of each of the three waters was dosed with I mg. $\mathrm{Mn} / \mathrm{m} .{ }^{3}$ and all illuminated under a strip-light. Counts of the Chlamydomonas were made after 6 and II days.

\begin{tabular}{lcc} 
Control (no pretreatment) & \multicolumn{3}{c}{$\begin{array}{c}\text { Chlamydomonas per mm. } \\
\text { on day }\end{array}$} \\
\cline { 2 - 3 } Pretreated with detritus & 45 & II \\
Pretreated with detritus and manganese & 35 & 44 \\
IOO
\end{tabular}

The same waters to which I mg. $\mathrm{Mn} / \mathrm{m} .{ }^{3}$ had been added $24 \mathrm{hr}$. after pretreatment with detritus and immediately before illumination.

Control

Pretreated with detritus

Pretreated with detritus and manganese
283

247 
The experiment shows that contact with the detritus rendered the water less fertile and the inference is drawn that it has done so by adsorbing manganese. It would further appear that where I mg. $\mathrm{Mn} / \mathrm{m} .{ }^{3}$ had been added at the same time as the detritus, all this added quantity had been taken up by the dead plant and animal cells.

An experiment was then made with marine bacteria, grown in sea water enriched with a trace of organic matter, killed by heat, and washed with several changes of filtered inshore water. A small addition of these bacterial corpses was made to an enriched inshore water to which I mg. Mn $/ \mathrm{m}^{3}$ and Chlamydomonas had been added. It reduced their growth rate. This experiment is inconclusive since some inhibitory substance might have leached into the culture from the washed corpses. A similar experiment was therefore made in which washed dead bacteria were added not only to water with small (I and $2 \mathrm{mg} . / \mathrm{m} .{ }^{3}$ ) additions of manganese, but also to water with relatively heavy additions ( 5 and I00 mg. $/ \mathrm{m}^{3}{ }^{3}$. It was thought that the abstraction by the corpses of a small proportion of the manganese in the latter would not materially reduce the growth of Chlamydomonas, whereas any inhibitory or poisonous substances leached out from them would reduce growth. The result of the experiment was that the addition of dead washed bacteria reduced growth in waters to which I and $2 \mathrm{mg}$. Mn had been added, but made no difference to the growth where 5 and $100 \mathrm{mg} . / \mathrm{m} .{ }^{3}$ had been added.

Another observation also points to the same conclusion, that very small amounts of manganese are adsorbed from sea water on some organic surfaces. The addition of glucose was found to increase the growth of Chlamydomonas in inshore water, but if an ample supply of manganese was added to the water glucose had no effect on the growth rate for several days. Later, however, as bacteria developed in the culture with glucose and manganese, the growth rate of the flagellate became materially less than in the control without the added sugar.

\section{Adsorption of Manganese on Inorganic Detritus}

Pettersson (1945) has investigated the possibility that manganese may be adsorbed on windborne inorganic dust after falling into the sea far from land, where manganese rich mud is continuously deposited on the bottom. His calculations indicate that some $15 \mathrm{mg}$. MnO are deposited annually below each square metre of the open ocean in depths averaging some $5000 \mathrm{~m}$.

Samples of powdered pumice and of volcanic ash were shaken with sea water to which a manganese salt had been added. Subsequent analysis showed no marked accumulation of manganese in the powders, and provided no evidence that windborne dust was likely to carry down with it any considerable quantity of manganese into the deep-sea deposits.

Pettersson draws attention to the presence of kaolinite and halloysite of terrestrial origin in these deep-sea deposits; this suggested using Chlamydomonas and Chlorella as analysts in order to find whether shaking inshore water, 
to which only I mg. $\mathrm{Mn} / \mathrm{m}^{3}$ had been added, with kaolin would remove any substantial part of this addition and thereby reduce the growth rate of these plants in the water. The experiments showed no marked reduction in growth rate, indicating that the kaolin had not adsorbed any substantial part of the manganese in the water.

It would appear, therefore, that manganese dissolved in ocean waters is probably not adsorbed on inorganic detritus, although it is readily adsorbed on living and recently dead organisms. As these sink and are broken down by bacterial attack and autolysis, taking perhaps two years before they finally reach the bottom, the manganese may or may not be de-adsorbed and pass back into solution. If it is de-adsorbed we would expect the surface layers beyond the influence of land drainage to be robbed of manganese; there is lack of observation showing the distribution of manganese in the ocean far from land.

\section{SUMMARY}

Inshore water collected near Plymouth during the late summer and autumn of 1945, after enrichment with nitrate, phosphate and iron, did not support continued growth of a species of Chlamydomonas, of Chlorella, of a Cryptomonad and of two species of Chrysomonads.

The addition of $0.5-2.0 \mathrm{mg}$. $\mathrm{Mn}$ " or $\mathrm{Mn}^{\mathrm{v}} / \mathrm{m}^{3}$ allowed vigorous growth and the production of heavy crops. The effect on Chlamydomonas of adding as little as $0.1 \mathrm{mg} . / \mathrm{m}^{3}{ }^{3}$ was apparent.

The growth of Coscinodiscus excentricus varied in waters collected from inshore and from offshore which had been similarly enriched with N, P and Fe. The addition of manganese had only a minor effect.

The addition of other microelements to inshore waters enriched with $\mathrm{N}$, $\mathrm{P}, \mathrm{Fe}$ and $\mathrm{Mn}$ did not affect growth rate of Chlamydomonas.

Manganese starvation led to the production of small Chlamydomonas cells.

Manganese starvation caused a resting condition or lag period in Chlorella. A supply of manganese alone was insufficient for recovery; a period of illumination was also required for internal changes to take place before logarithmic growth was resumed.

The addition of manganese was effective when either nitrate or ammonium was supplied as source of nitrogen, in dim, bright, continuous, or discontinuous illumination.

Metabolic products which leached out of the cells into the water during the growth of both Chlorella sp. and of Nitzschia closterium acted as a growth stimulant.

Manganese at great dilution is rapidly 'collected' from solution by Chlorella. During growth this alga abstracts a material proportion from water containing $5 \mathrm{mg}$. $\mathrm{Mn} / \mathrm{m}^{3}{ }^{3}$ 
Using Chlamydomonas as 'analyst', it was found that added organic detritus, or the corpses of marine bacteria, adsorbed a material proportion of the manganese in sea water containing I-2 $\mathrm{mg} . \mathrm{Mn} / \mathrm{m} .^{3}$

\section{REFERENCES}

AlgeUs, S., 1946. Untersuchungen über die Ernährungsphysiologie der Chlorophyceen. Lund.

Allen, E. J., I9I4. On the culture of the plankton diatom Thalassiosira gravida Cleve, in artificial sea water. Fourn. Mar. Biol. Assoc., Vol. x, pp. 4I7-39.

Allen, E. J. \& Nelson, E. W., I9I0. On the artificial culture of marine plankton organisms. Quart. Fourn. Micr. Sci., Vol. LV, pp. 36I-43I.

Cooper, L. H. N., I939. Phosphorus, nitrogen, iron and manganese in marine zooplankton. Fourn. Mar. Biol. Assoc., Vol. xxIII, pp. 387-90.

Correns, W., I94I. Nachr. Akad. Wiss. Göttingen, Math.-Phys. Klasse, Bd. 5, p. II9. (Quoted by Pettersson, I945.)

EMERSON, R. \& LewIS, C., I939. The quantum efficiency of photosynthesis. Carnegie Inst. Year Book, Vol. xxxIx, pp. 154-8.

Hart, T. J., I94I. Phytoplankton periodicity in Antarctic surface waters. Discovery Rep., No. 2I, pp. 26I-356.

Harvey, H. W., I937. The supply of iron to diatoms. Fourn. Mar. Biol. Assoc., Vol. xxir, pp. 205-19.

- 1939. Substances controlling the growth of a diatom. Fourn. Mar. Biol. Assoc., Vol. XxIII, pp. 499-520.

Kylin, H., I94I. Biologische Analyse des Meerwassers. Fysiogr. Sällsk. Forhandl. Lund, Bd. II, No. $2 \mathrm{I}$.

_ 1942. Über den Einfluss von Glucose, Ascorbinsäure und Heteroauxin auf die Keimlinge von Ulva und Enteromorpha. Fysiogr. Sällsk. Forhandl. Lund, Bd. I2, No. I2.

— I943. Úber die Ernährung von Ulva lactuca. Fysiogr. Sällsk. Forhandl. Lund, Bd. I3, No. 2 I.

- I 945 . Weitere Angaben über die Ernährung von Ulva lactuca. Fysiogr. Sällsk. Forhandl. Lund, Bd. I5, No. 3 .

LeVRING, T., I945. Some culture experiments with marine plankton diatoms. Göteborgs Kungl. vetenskaps och Vitterhets samhälles Handlingar (6), Ser. B, Bd. 3, No. I2, I8 pp.

- I946. Some culture experiments with Ulva and artificial sea water. Fysiogr. Sällsk. Forhandl. Lund, Bd. I6, No. 7.

MATUdiarA, T., I939. The physiological property of sea water considered from the effect upon the growth of diatom, with special reference to its vertical and seasonal change. Bull. Fap. Soc. Sci. Fish., Vol. viII, pp. I87-93.

NoAck, K. \& Pirson, A., I939. Die Wirkung von Eisen und Mangan auf die Stichstoffassimilation von Chlorellen. Ber. dtsch. bot. Ges., Bd. 57, p. 422.

NodDack, I. \& NoDDACK, W., I940. Die Häufigkeiten der Schwermetalle in Meerestieren. Archiv für Zoologie, Bd. 32, No. I, p. I.

Pettersson, H., I945. Iron and manganese on the ocean floor. Göteborgs Kungl. vetenskaps och Vitterhets samhälles Handlingar (6), Ser. B, Bd. 3, No. 8, $37 \mathrm{pp}$.

PIRSON, A., I937. Ernährungs- und stoffwechselphysiologische Untersuchungen an Fontinalis und Chlorella. Z. Bot., Bd. 31, pp. 193-267. 
RILEY, G. A., I943. Physiological aspects of spring diatom flowerings. Bull. Bingham Oceanogr. Coll., Vol. virr, Art. 4, 53 pp.

SCHREIBER, E., I929. Die Methoden einer physiologischen Meerwasseranalyse. Rapp. Cons. Explor. Mer, T. 53, pp. 75-9.

SUNESON, S., I942. Über wachstumsfördernde Wirkung von Algenextrakten auf Ulva und Enteromorpha. Fysiogr. Sällsk. Forhandl. Lund, Bd. I2, No. I6.

— 1943. Weitere Untersuchungen über wachstumsfördernde Wirkung von Algenextrakten auf Ulva lactuca. Fysiogr. Sällsk. Forhandl. Lund, Bd. I3, No. 20.

Thompson, T. G. \& WILsON, T., I935. The occurrence and determination of manganese in sea water. Fourn. Amer. Chem. Soc., Vol. LvII, pp. 233-6.

DE VALERA, M., I940. Note on difference in growth of Enteromorpha species in various culture media. Fysiogr. Sällsk. Forhandl. Lund, Bd. Io.

ZoBell, C. E. I946. Marine Microbiology. Watham, Mass., U.S.A. 